\title{
Description of the growth of pequi fruits by nonlinear models
}

\author{
Thais Destefani Ribeiro', Ricardo Wagner Pacopahyba de Mattos ${ }^{2}$, \\ Augusto Ramalho de Morais ${ }^{3}$, Joel Augusto Muniz ${ }^{4}$ \\ Abstract-Pequi tree is a species native to the Brazilian cerrado, with wide geographic distribution, whose fruit \\ is very appreciated in cooking, composing traditional dishes. In general, pequi fruit is consumed when ripe \\ in the fresh form or in the various derived products such as oils, liqueurs, sweets, ice creams among others, \\ involving important socioeconomic activity generating employment and income in family agriculture. The \\ aim of this study was to evaluate the adjustment of Brody, Gompertz, Logistic and Von Bertalanffy models \\ in the growth and development of pequi fruits based on their physical characteristics such as longitudinal \\ and cross-sectional diameter and fresh mass obtained over time. Parameters were estimated using R software \\ routines, using the least squares method and the Gauss-Newton iterative process. The adjustment of models \\ was compared using the following criteria: residual standard deviation, adjusted determination coefficient \\ and corrected Akaike information criterion. In general, data presented no correlation error structure and \\ the Von Bertalanffy model did not fit fresh mass data. The models presented good quality in the adjustment \\ to pequi growth data, except for the Brody model for fresh mass. The Gompertz and Logistic models were \\ those that best described variables, and the Gompertz model was the most suitable to describe diameter and \\ mass data. Based on the adjustment, a slow initial growth was observed up to about 20 days after anthesis; \\ after this period, the fruit developed more rapidly up to 90 days and then presented a tendency to stability \\ until the end of the evaluation period at 117 days after anthesis, with sigmoid curve character. Pequi fruits \\ obtained final average value of $7.1 \mathrm{~cm}$ for cross-sectional diameter, $6.8 \mathrm{~cm}$ for longitudinal diameter and \\ $113 \mathrm{~g}$ for fresh mass. \\ Index terms: Growth models, biometric measurements, sigmoid curves, adjustment of models, pequi.

\section{Descrição do crescimento de frutos de pequizeiro por modelos não lineares}

Corresponding author:

t.destefani.ribeiro@gmail.com

Received:August 14, 2017.

Accepted: October 23, 2017.

Copyright: All the contents of this journal, except where otherwise noted, is licensed under a Creative Commons Attribution License.

\section{(cc) $\mathrm{EY}$}

Resumo - O pequizeiro é uma espécie nativa do cerrado brasileiro, com ampla distribuição geográfica, cujo fruto é bastante apreciado na culinária, compondo pratos tradicionais. Em geral, o fruto do pequi é consumido quando maduro, na forma in natura ou nos diversos, produtos derivados tais como óleos, licores, doces, sorvetes, entre outros, envolvendo importante atividade socioeconômica geradora de emprego e renda na agricultura familiar. Este trabalho teve por objetivo avaliar o ajuste dos modelos Brody, Gompertz, Logístico e Von Bertalanffy no crescimento e no desenvolvimento de frutos de pequi, com base em suas características físicas, como diâmetro longitudinal e transversal, e massa fresca obtidos ao longo do tempo. Os parâmetros foram estimados por meio de rotinas do software R, utilizando-se do método de mínimos quadrados e o processo iterativo de Gauss-Newton. O ajuste dos modelos foi comparado, utilizando os critérios: desvio-padrão residual, coeficiente de determinação ajustado e critério de informação de Akaike corrigido. Em geral, os dados não apresentaram estrutura de erros correlacionados, e o modelo Von Bertalanffy não se ajustou aos dados de massa fresca. Os modelos apresentaram boa qualidade no ajuste aos dados de crescimento de pequi, exceto o modelo Brody para a variável massa fresca. Os modelos Gompertz e Logístico foram os que melhor descreveram as variáveis, sendo o Gompertz o mais indicado para descrever os dados de diâmetro e de massa. Com base no ajuste, observou-se um crescimento inicial lento até cerca de 20 dias após a antese; após este período, o fruto desenvolveu-se de modo mais acelerado até 90 dias e, então, apresentou tendência à estabilidade até o final da avaliação, aos 117 dias após a antese, com caráter sigmoide da curva. O fruto de pequizeiro obteve valores finais, em média, de $7,1 \mathrm{~cm}$ de diâmetro transversal, $6,8 \mathrm{~cm}$ de diâmetro longitudinal e $113 \mathrm{~g}$ de massa fresca.

Termos de indexação: Modelos de crescimento, medidas biométricas, curvas sigmoides, ajuste de modelos, pequi. 


\section{Introduction}

Pequi tree is a native tree symbol of the Brazilian cerrado belonging to the family Caryocaraceae, including 25 species, being Caryiocar brasiliense Cambess the most common (OLIVEIRA et al., 2008). The word pequi is of indigenous origin and means "prickly peal". Pequi fruit, also called piqui, pequiá, pitiá, pequerim and saco-de-bode is much appreciated by the population, being the base of the food culture of several Brazilian regions, composing traditional recipes like rice with pequi, "galinhada", sweets, liqueurs and ice creams. Popularly, pequi oil, flowers and leaves are used as herbal medicines, with indications for several treatments of home medicine (CARRAZZA; D'ÁVILA, 2010).

The species produces oleaginous fruits and represents an important source of income for family farming. It has relevant socioeconomic importance due to the large number of jobs generated by activities involved from fruit collection, transportation and processing, marketing and consumption in the fresh form, or derived products (MEDAETS, 2006). It is present in all regions of the country, with emphasis on CE, BA, DF, GO, MA, MG, MS, MT, PA, PE, PI, PR, RJ and SP states (CARVALHO, 2009), and the Brazilian pequi fruit production reached 18.8 thousand tons in 2015 and that of pequi almonds was 2.2 thousand tons in the same year (IBGE, 2017). Pequi pulp presents chemical composition rich in fatty acids, with predominance of oleic and palmitic acids (ALMEIDA, 1998). The high oil content in the pulp and almond classifies the species as potential for biofuel production (DUBOC et al., 2013).

The study of the development and growth process of plants and fruits, measuring the accumulation of biomass over time, has wide application in agronomic research, enabling the researcher to understand the behavior of biological variables in different situations (PRADO et al., 2013b; TERRA, et al., 2010). The study of the fruit growth pattern allows establishing harvesting procedures, handling techniques and post-harvest conservation, obtaining better maturation and fruit quality indexes (ARAÚJO NETO et al., 2001; MUIANGA et al. 2016). In general, the harvest point is one of the main post-harvest loss factors and, in most situations, it is subjectively determined, based on the fruit external color and size, and there is no consensus among producers in the various species (CAVALINI et al., 2006).

In the fruit growth evaluation, several studies have used nonlinear regression models, which are more appropriate than linear ones, since they summarize data information in a few parameters with practical interpretation (BALAGUERA-LÓPEZ et al., 2012; MARO et al., 2012; PRADO et al., 2013a; FERNANDES et al., 2014). Nonlinear models have been used in studies in crops with satisfactory results, allowing estimations of fruit growth parameters with biological interpretation with pygmy date palm (TERRA et al., 2010), green dwarf coconut (PRADO et al., 2013b ), cashew (MUIANGA et al., 2016) and cacao fruit (MUNIZ et al., 2017). For coffee crop, models were used in the description of the seed germination curve (SOUSA et al., 2014), in a plant height growth study (PEREIRA et al., 2014) and canopy diameter (WYZYKOWSKI et al. al., 2015).

Considering the adjustment of nonlinear models, the estimation of parameters from the classical point of view is usually performed based on the minimization of the sum of squares of residuals, which leads to a system of normal equations with no analytical solution, so iterative processes should be used to obtain estimates (DRAPER, SMITH, 1998; SOUZA, 2007). Several iterative methods are used, especially Gauss-Newton (PEREIRA et al., 2005; MENDES et al., 2008; ZEVIANI et al., 2012; CARNEIRO et al., 2014; FERNANDES at al., 2015). In regression studies, it is usual to admit in the estimation process and inference under parameters that the errors are independent, which does not necessarily occur when working with time-ordered data that are potentially correlated (CASSIANO; SÁFADI, 2015). In this case, the model parameters estimates can be biased, with values below or above the actual value (GUEDES et al., 2014; MAZZINI et al., 2005; FERNANDES et al., 2014), and one should consider the autocorrelation structure present in data in the model adjustment (PRADO et al., 2013a; RIBEIRO et al., 2018), as it may affect the value of the standard error estimate.

The aim of this study was to evaluate the adjustment of nonlinear Brody, Gompertz, Logistic and Von Bertalanffy models in the description of pequi fruit growth considering the autoregressive structure for errors based on their physical characteristics.

\section{Material and methods}

Data used to fit the models were obtained in an experiment conducted by Rodrigues et al. (2009) in the municipality of Itumirim, MG, in an area of native pasture, with typical cerrado formation and with predominance of Caryocar brasiliense Camb. Sixty trees of the species were selected, with homogeneous size, identifying the open flowers in different plant positions during anthesis. The researchers evaluated fruit growth and development, making measurements of cross-sectional and longitudinal diameters, in cm, as well as fresh mass in grams. Twelve days after anthesis, fruits were collected and measured, which continued to be done every fifteen days until the beginning of the fruit abscision that took place 117 days after anthesis, totaling eight ages and thus obtaining the average values for each measure. 
The Brody (B), Gompertz (G), Logistic (L) and Von Bertalanffy (VB) growth models were adjusted, described by the following expressions, respectively:

$Y_{i}=A\left\{1-\mathrm{B} \exp \left(-K_{t i}\right)\right\}+\mathrm{u}_{i},(1), \quad Y_{i}=A \exp \left\{-\exp \left(B-K_{t i}\right)\right\}+\mathrm{u}_{i}, \quad$ (2) $Y_{i}=A /\left\{1-\exp \left(\mathrm{B}-K_{t i}\right)\right\}+\mathrm{u}_{i},(3), \quad Y_{i}=A\left\{1-\exp [(-K(t i-B)]\}^{3}+\mathrm{u}_{i},(4)\right.$

Where $\mathrm{u}_{i}=\phi_{1} u_{\mathrm{i}-1}+\ldots+\phi_{\mathrm{p}} \mathrm{u}_{i-p}+\varepsilon_{i}$, with $\mathrm{i}=1,2, \ldots, \mathrm{n}$ and $\mathrm{n}=8$, the number of times pequi fruits were measured; $\mathrm{u}_{i}$ is the residual of adjustment at the $\mathrm{i}$-th time; $\phi_{1}$ is the autoregressive parameter of order $1 ; u_{\mathrm{i}-1}$ is the residual of time immediately before the i-th measure; $\phi_{p}$ is the autoregressive parameter of order $\mathrm{p} ; u_{\mathrm{i}-1}$ is the residual of adjustment in $\mathrm{p}$ times before the $\mathrm{i}$-th measure; $\varepsilon_{i}$ is the white residual with normal distribution $\mathrm{N}\left(0, \alpha^{2}\right)$. When the residuals are independent, parameters $\phi_{i}$ will be null, and consequently $\mathrm{u}_{i}=\varepsilon_{i}$ (MAZZINI et al., 2005; GUEDES et al., 2014).

In equations (1), (2), (3) and (4), Yi defines the mean values $(\mathrm{cm})$, of longitudinal and cross-sectional diameters and fresh mass $(\mathrm{g})$ of pequi fruits at times $\mathrm{t}_{\mathrm{i}}$; $\mathrm{t}_{\mathrm{i}}$ refers to the time of the $\mathrm{i}$-th measurement, expressed in days after full bloom; A indicates the asymptotic value of measures, that is, the value of variables when the fruit is fully developed; $\mathrm{B}$ represents the location parameter, without biological interpretation; $\mathrm{k}$ is the ratio of the maximum growth rate in relation to each final measure (Measure Unit day ${ }^{-1}$ ), being variable in time, and reaches maximum growth where the inflection point occurs. According to Freitas (2005), the Gompertz, Logistic and Von Bertalanffy models present an inflection point, that is, a change in the curve concavity, in $Y_{i}=A / e$, where, $\mathrm{e}=2,7182, Y_{i}=A / e$ and $=Y_{i}=8 A / 27$ respectively. These results indicate that in the Gompertz and Von Bertalanffy models, the maximum growth rate occurs before reaching half of the maximum development and for the Logistic model, it occurs when the fruit reaches half of its development, showing to be symmetrical. The Brody model does not present inflection point due to its characteristics. For the adjustment of models, R software (R DEVELOPMENT CORE TEAM, 2016) was used.

To verify the homogeneity of variances and normality of residuals, the Breusch and Pagan tests were used as described by Breusch and Pagan (1979) and Shapiro-Wilk, described by Shapiro and Wilk (1965), respectively, as well as the graphical analysis of residuals. To evaluate the existence of residual autocorrelation, the Durbin-Watson test (DURBIN, WATSON, 1950) was applied. The comparison of models took into account the agronomic interpretation of parameter estimates and also the quality of the adjustment based on the values of evaluators, Residual Standard Deviation (RSD), Adjusted Determination Coefficient $\left(\mathrm{R}_{\mathrm{aj}}^{2}\right)$ and Corrected Akaike Information Criterion ( DRAPER, SMITH, 1998; GUTHERY et al., 2003).

\section{Results and discussion}

Table 1 shows the results obtained for the ShapiroWilk (SW), Breusch-Pagan (BP) and Durbin-Watson (DW) tests and Figures 1, 2 and 3 show the graphical analyses for the residuals of the Brody, Gompertz, Logistic and Von Bertalanffy models adjusted to pequi growth data. DW tests were not significant for all variables, indicating that the residues had no dependence. These results were consistent with the fact that biometric measurements were made on different fruits at each age. Similar results were found by Lúcio et al (2016) in a study with the production of cherry tomato when evaluating the mean values in different fruits, since they also found independence of errors. On the other hand, discordant results were obtained by Muianga et al. (2016) and Sousa et al. (2014), who observed autocorrelated errors in their studies of adjustment of nonlinear regression models, respectively, in the description of cashew fruit growth and in the study on the germination of coffee seeds both with average data of the same fruits.

After the study on residual dependence, it was verified that the assumptions of normality and homogeneity of variance of the residual vector were met for variables cross-sectional diameter $(\mathrm{cm})$, longitudinal diameter $(\mathrm{cm})$ and fresh mass $(\mathrm{g})$ of pequi fruits for the evaluated models ( $p$-value $>0.05$ ). In Figures 1, 2 and 3, it was possible to observe that the graphical analysis of residues corroborated the results obtained by the SW and BP tests presented in Table 1, showing no bias in residuals and normality. The Von Bertalanffy model did not fit the pequi fresh mass data, thus the estimates and inferences made are not presented for the model in this variable.

Table 2 shows the estimates of parameters and the respective $95 \%$ confidence intervals, based on the adjustment of Brody, Gompertz, Logistic and Von Bertalanffy models, for the cross-sectional measurements $(\mathrm{cm})$ of pequi fruits, taken in eight times, as well as the quality adjustment evaluators of models. The Gompertz and Logistic models had confidence intervals with less amplitude than the Von Bertalanffy and Brody models. For all models, the determination coefficient $\left(\mathrm{R}_{\mathrm{aj}}^{2}\right)$ values were higher than 0.98 , indicating satisfactory adjustments.

Regarding the residual standard deviation (RSD) and corrected Akaike information criterion (AIC), the Gompertz model presented lower values and according to results obtained by Fernandes et al. (2015), the lower AIC and RSD values suggest that the model best describes data. Therefore, adjustment quality evaluators point out superiority of the Gompertz model to describe the crosssectional growth of pequi fruits.

Based on estimates of parameter A by models presented in Table 2, it could be observed that the final cross-sectional diameter of pequi fruits obtained with the adjustment of the Gompertz and Logistic models was in 
accordance with values obtained by Moura et al. (2013), who found average value of $7.4 \mathrm{~cm}$ for the cross-sectional diameter of pequi fruits in their studies. On the other hand, the Brody and Von Bertalanffy models overestimated the final cross-sectional diameter of pequi fruits based on Moura et al. (2013) and Rodrigues et al. (2009). The Gompertz model was the closest to actual estimates, the growth rate for the cross-section of pequi fruits was 0.04 $\mathrm{cm} /$ day.

Table 3 shows the estimates of parameters and the respective $95 \%$ confidence intervals based on the adjustment of Brody, Gompertz, Logistic and Von Bertalanffy models for the longitudinal diameter measurements $(\mathrm{cm})$ of pequi fruits, taken in eight times, as well as the quality adjustment evaluators of models. The parameters of models evaluated were different from zero, since the confidence intervals did not go through zero, indicating quality in obtaining estimates, and the Gompertz and Logistic models presented intervals with smaller amplitude. For all models, the $\mathrm{R}_{\text {aj }}{ }_{\text {aj }}$ values were equal to or greater than 0.98 , indicating good fit to experimental data. As for AIC and RSD values, the Gompertz model presented lower values, suggesting that this model best describes data, as well as for the longitudinal diameter $(\mathrm{cm})$. Similar results were found by Prado et al, (2013b), who also observed good fit of the Gompertz model in a study on the diameter growth of green dwarf coconut fruits.

Based on estimates of parameter (A) obtained by models presented in Table 3, it was observed that the final longitudinal diameter of pequi fruits for the Gompertz and Logistic models were closer to values obtained by Moura et al. (2013) and Rodrigues et al. (2009), who found average value of $6.5 \mathrm{~cm}$, and distant from the results of Vera et al. (2007), who observed value of $5.54 \mathrm{~cm}$ for the cross-sectional diameter. It is interesting to note that the confidence interval of the Gompertz model was the only one that covers the value obtained by Moura et al. (2013) and Rodrigues et al. (2009) for the variable. It is also noteworthy that it presented average growth rate of $0.042 \mathrm{~cm} /$ day. The values obtained for the cross-sectional and longitudinal diameter of pequi fruits were close and consistent with Vera et al. (2007), who affirmed that these measures are similar due to the spherical shape of pequi fruits.

The differences observed in the results of this study in relation to values found in literature for the physical measurements of pequi fruits (MOURA et al., 2013; RODRIGUES et al., 2009; VERA et al., 2007) are justified by Moura et al. (2013) due to the great phenotypic variability of the species, considering its wide geographic distribution.

Table 4 presents the estimates of parameters and their $95 \%$ confidence intervals based on the adjustment of Brody, Gompertz and Logistic models, for the fresh mass measurement ( $\mathrm{g}$ ) of pequi fruits, taken in eight times, as well as the quality adjustment evaluators of models. The parameters of Gompertz and Logistic models were different from zero because small amplitude confidence intervals did not pass through zero, since the Brody model presented wider intervals in general, and one of its parameters $B$ can assume the null value. $R^{2}$ ij dicated better fit quality for the Gompertz and Logistic models with values above 0.99 . The AIC and RSD values were smaller for the Gompertz model, indicating better fit of data, followed by the Logistic model. Similar results were obtained, respectively, by Sousa et al. (2014) when comparing Logistic and Gompertz models in the description of coffee seed germination.

Based on estimates of parameters obtained by the Gompertz model, it was observed that the final fresh mass of pequi fruits was on average $113 \mathrm{~g}$, corroborating results obtained by Rodrigues et al (2009) and disagreeing with results of Moura et al. (2013), who observed a national average value according to the six regions studied of $180 \mathrm{~g}$ for total fruit mass and on average $200 \mathrm{~g}$ for the northern region of Minas Gerais. The logistic model presented average estimates slightly lower than the Gompertz model. However, the Brody model overestimated the final fresh mass of pequi fruits (MOURA et al., 2013). The average growth rate for fruit mass was $0.069 \mathrm{~g}$ / day according to the Gompertz model, which best fit for the variable.

Figures 4, 5 and 6 show the graphs of the adjustment of Brody, Gompertz, Logistic and Von Bertalanffy models to the growth data of pequi fruits for variables cross-sectional diameter $(\mathrm{cm})$, longitudinal diameter $(\mathrm{cm})$ and fresh mass $(\mathrm{g})$ respectively. For all variables, it is possible to clearly see the sigmoidal shape of the fruit development, also observed by Rodrigues et al. (2009) with the pequi characterization, Muianga et al. (2016), when describing cashew growth and by Muniz et al. (2017) in studies on cacao fruit growth and Ribeiro et al. (2018) in their studies with the growth of Asian pear fruits. It is interesting to note that, despite the small number of measures used in the study, the sigmoidal growth character was verified and there was enough quality in the model parameters estimation.

As shown in Figures 4 and 5, the four models evaluated were adjusted to the length and cross-sectional diameter data of fruits, especially by the Gompertz model, which most approximated the observed values, corroborating results of evaluators presented in Tables 2 and 3. With respect to the diameter growth, it could be observed that the fruit presented accelerated development until about 90 days after anthesis, and after this period, development slowed down until the fruit was harvested at 117 days after anthesis. It was observed that about $77 \%$ of fruit development occurred in relation to the cross-sectional and longitudinal diameter characteristics. These observations agree with results of Rodrigues et al. 
(2009) on the growth stages of pequi fruits, which is also characteristic of fruits of other species, such as the Asian pear described by Fioravanço and Antoniolli (2016).

For the fresh mass of fruits (g) shown in Figure 6, it could be observed that the Gompertz model was closer to observed values, followed by the Logistic model, which was not observed with the Brody model that in addition to being far from the central observations, extrapolated the asymptotic value. Initially, the growth occurred slowly up to about 20 days and thereafter, it showed a more accelerated development, stabilizing after 90 days, as well as for cross-sectional and longitudinal diameters. Rodrigues et al. (2009) also observed a slow initial growth in diameters and fresh mass, after this period, an accelerated development up to 87 days was observed, and then growth slows down up to 102 days until the end of the evaluation of pequi fruits. The maturation point of pequi fruits may depend on regional characteristics such as water and organic matter availability, incidence of sun among others, and it is possible to observe different maturation stages in relation to different regions and even among regions, which may result in a change in volume and fruit mass (MOURA et al., 2013; VERA et al., 2007).

Based on the structure of the Gompertz model that best fit the cross-sectional diameter growth of fruits, the inflection point occurred before reaching half of the maximum fruit development, i.e.: $\mathrm{Y}=7,11 / 2,7182=$ $2.62 \mathrm{~cm}$ at 35 days after anthesis. For the longitudinal diameter, the inflection point of growth occurred when fruit reached $2.52 \mathrm{~cm}$ at 35 days as well as for the cross-sectional diameter, which was expected due to the spherical characteristic of fruits. Fresh mass presented its inflection point with $41.6 \mathrm{~g}$ at 45 days after anthesis, being slightly later than the other variables.

Table 1. P-value for the following tests: Shapiro-Wilk (SW), Breusch-Pagan (BP) and Durbin-Watson (DW) in residual analysis after adjustment of Brody, Gompertz, Logistic and Von Bertalanffy models to the cross-sectional diameter, longitudinal diameter and fresh weight of pequi fruits.

\begin{tabular}{ccccc}
\hline \multicolumn{5}{c}{ Cross-Sectional Diameter } \\
\hline Tests/Models & Logistic & Gompertz & Von Bertalanffy & Brody \\
\hline SW & 0.6146 & 0.3675 & 0.7372 & 0.7173 \\
BP & 0.0721 & 0.1130 & 0.6789 & 0.1130 \\
DW & 0.7940 & 0.9420 & 0.2020 & 0.9200 \\
\hline \multicolumn{5}{c}{ Longitudinal Diameter } \\
SW & 0.8063 & 0.5240 & 0.2232 & 0.9111 \\
BP & 0.1117 & 0.2126 & 0.9500 & 0.3986 \\
DW & 0.2580 & 0.4620 & 0.3720 & 0.0600 \\
\hline SW & 0.3566 & 0.6174 & - & 0.7723 \\
BP & 0.4173 & 0.0608 & - & 0.3804 \\
DW & 0.2400 & 0.0780 & - & 0.3040 \\
\hline
\end{tabular}

Table 2. Estimations of parameters and their Confidence Intervals (LI ; LS) for the adjustment of Brody (Bd), Gompertz (G), Logistic (L) and Von Bertalanffy (VB) models to the cross-sectional diameter ( $\mathrm{cm}$ ) data of pequi fruits and quality indicators of fit.

\begin{tabular}{ccccccc}
\hline $\begin{array}{c}\text { Estimate } / \\
\text { Evaluator }\end{array}$ & $\mathrm{A}$ & $\mathrm{B}$ & $\mathrm{K}$ & $\mathrm{R}_{\text {aj }}$ & $\mathrm{AICc}$ & $\mathrm{DPR}$ \\
\hline $\mathrm{Bd}$ & 8.23 & 1.24 & 0.018 & 0.98 & 15.97 & 0.173 \\
$\mathrm{IC}$ & {$[6.90 ; 11.57]$} & {$[1.05 ; 1.51]$} & {$[0.009 ; 0.029]$} & - & - & - \\
$\mathrm{G}$ & 7.11 & 35.09 & 0.04 & 0.99 & 11.20 & 0.129 \\
$\mathrm{IC}$ & {$[6.56 ; 7.85]$} & {$[30.76 ; 39.73]$} & {$[0.032 ; 0.058]$} & - & - & - \\
$\mathrm{L}$ & 6.85 & 43.93 & 0.068 & 0.98 & 13.67 & 0.145 \\
$\mathrm{IC}$ & {$[6.34 ; 7.49]$} & {$[38.60 ; 49.84]$} & {$[0.049 ; 0.093]$} & - & - & - \\
$\mathrm{VB}$ & 8.23 & 11.47 & 0.006 & 0.98 & 15.97 & 0.180 \\
$\mathrm{IC}$ & {$[6.91 ; 11.57]$} & {$[4.36 ; 15.88]$} & {$[0.003 ; 0.009]$} & - & - & - \\
\hline
\end{tabular}


Table 3. Estimations of parameters and their Confidence Intervals (LI ; LS) for the adjustment of Brody (Bd), Gompertz (G), Logistic (L) and Von Bertalanffy (VB) models to the cross-sectional diameter ( $\mathrm{cm}$ ) data of pequi fruits and quality indicators of fit.

\begin{tabular}{ccccccc}
\hline $\begin{array}{c}\text { Estimate } / \\
\text { Evaluator }\end{array}$ & $\mathrm{A}$ & $\mathrm{B}$ & $\mathrm{K}$ & $\mathrm{R}_{\text {aj }}^{2}$ & $\mathrm{AICc}$ & $\mathrm{DPR}$ \\
\hline $\mathrm{Bd}$ & 8.11 & 1.24 & 0.019 & 0.99 & 11.37 & 0.128 \\
$\mathrm{IC}$ & {$[7.07 ; 10.14]$} & {$[1.08 ; 1.43]$} & {$[0.012 ; 0.027]$} & - & - & - \\
$\mathrm{G}$ & 6.85 & 34.08 & 0.042 & 0.99 & 10.57 & 0.123 \\
$\mathrm{IC}$ & {$[6.54 ; 7.83]$} & {$[29.81 ; 38.76]$} & {$[0.032 ; 0.056]$} & - & - & - \\
$\mathrm{L}$ & 7.08 & 43.20 & 0.064 & 0.98 & 15.39 & 0.167 \\
$\mathrm{IC}$ & {$[6.25 ; 7.62]$} & {$[36.93 ; 50.49]$} & {$[0.045 ; 0.092]$} & - & - & - \\
$\mathrm{VB}$ & 8.11 & 10.94 & 0.006 & 0.98 & 11.37 & 0.129 \\
$\mathrm{IC}$ & {$[7.07 ; 10.15]$} & {$[5.82 ; 14.45]$} & {$[0.004 ; 0.009]$} & - & - & - \\
\hline
\end{tabular}

Table 4. Estimations of parameters and their Confidence Intervals (LI ; LS) for the adjustment of Brody (Bd), Gompertz $(\mathrm{G})$, Logistic (L) and Von Bertalanffy (VB) models to the fresh weight (g) data of pequi fruits and quality indicators of fit.

\begin{tabular}{ccccccc}
\hline $\begin{array}{c}\text { Estimate / } \\
\text { Evaluator }\end{array}$ & $\mathrm{A}$ & $\mathrm{B}$ & $\mathrm{K}$ & $\mathrm{R}_{\text {aj }}^{2}$ & $\mathrm{AICc}$ & $\mathrm{DPR}$ \\
\hline $\mathrm{Bd}$ & 172.88 & 1.24 & 0.012 & 0.91 & 75.39 & 7.100 \\
$\mathrm{IC}$ & {$[158.68 ; 187.08]$} & {$[-3.92 ; 6.4]$} & {$[0.003 ; 0.021]$} & - & - & - \\
$\mathrm{G}$ & 113.12 & 45.14 & 0.069 & 0.99 & 49.63 & 1.419 \\
$\mathrm{IC}$ & {$[107.99 ; 119.90]$} & {$[42.96 ; 47.29]$} & {$[0.057 ; 0.0876]$} & - & - & - \\
$\mathrm{L}$ & 110.73 & 51.15 & 0.106 & 0.99 & 52.35 & 1.678 \\
$\mathrm{IC}$ & {$[105.52 ; 116.31]$} & {$[48.49 ; 53.89]$} & {$[0.084 ; 0.135]$} & - & - & - \\
\hline
\end{tabular}
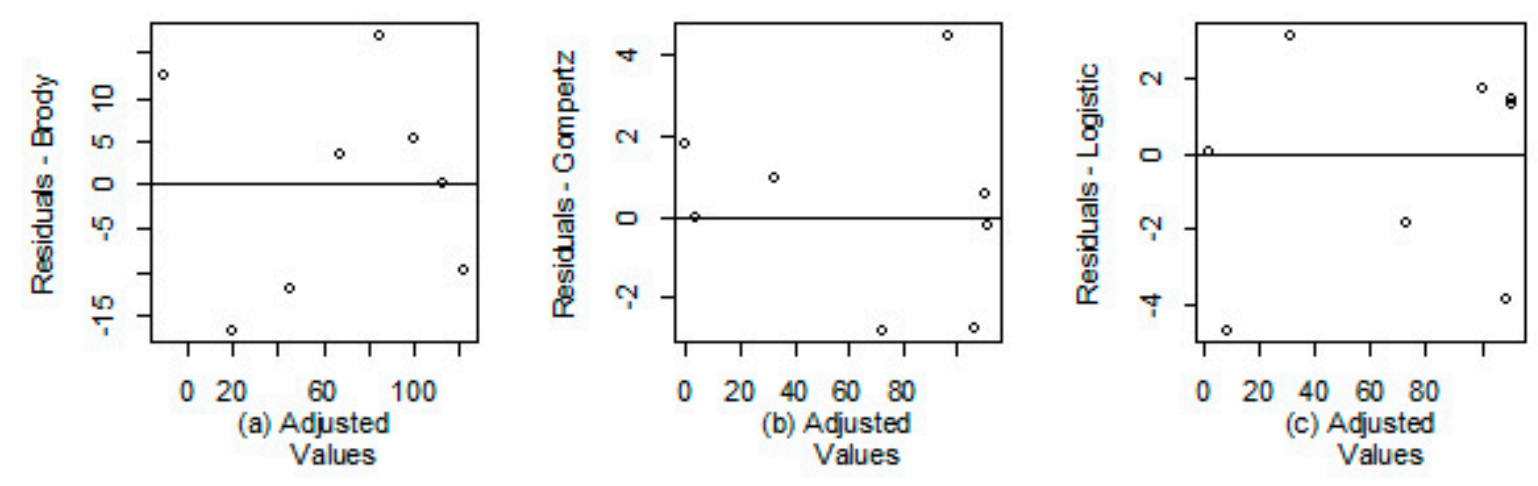

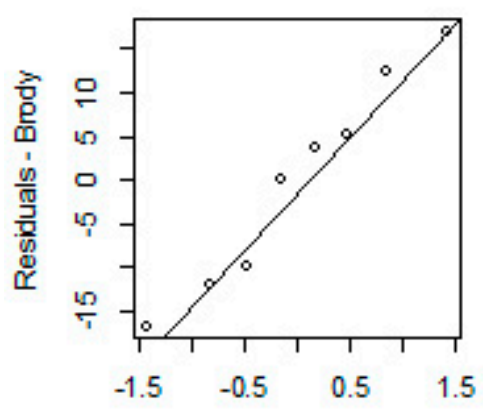

(d)Theoretical Amounts

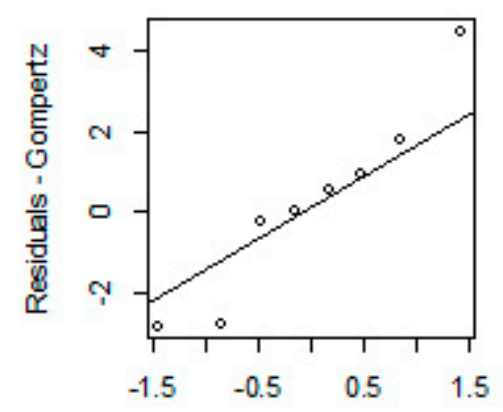

(e) Theoretical Amounts

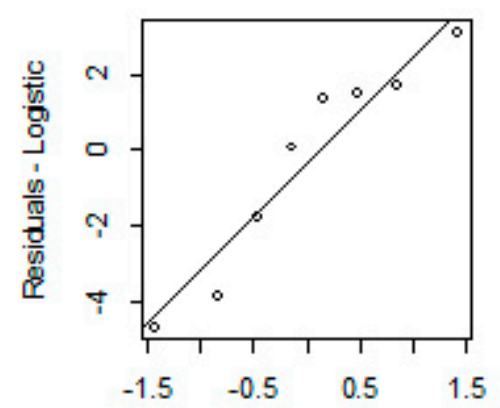

(f) TheoreticalAmounts

Figure 1. Residual analysis for fresh mass (g), where (a), (b) and (c) represent the adjusted values in relation to residuals, and in (d), (f) and (g), residual values in relation to theoretical amounts for the Brody, Gompertz and Logistic models, respectively. 

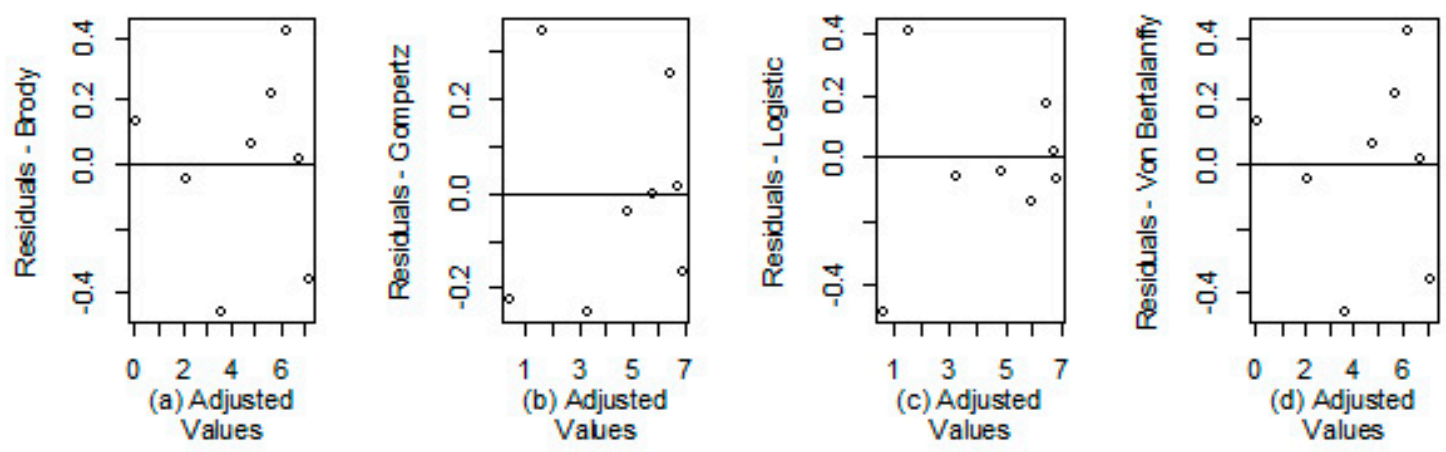

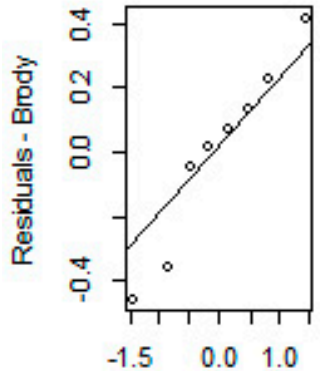

(e) Theoretical Amounts

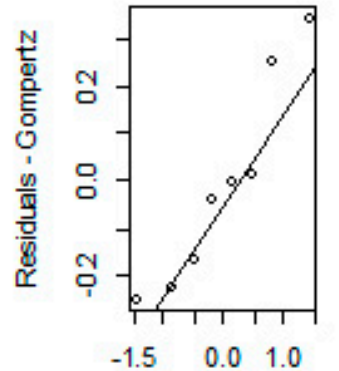

(f) Theoretical Amounts

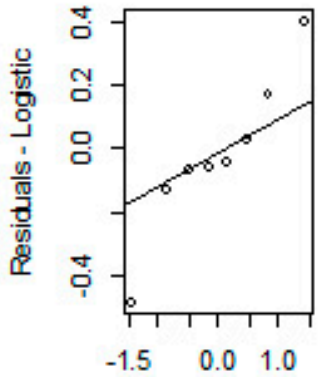

(g) Theoretical Amounts

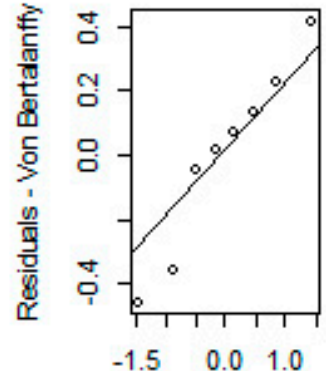

(h) Theoretical Amounts

Figure 2. Residual analysis for the Cross-sectional Diameter (cm), where (a), (b), (c) and (d) represent the adjusted values in relation to residuals, and in (e), (f), ( g) and (h), the residual values in relation to theoretical amounts for Brody, Gompertz, Logistic and Von Bertalanffy models, respectively.
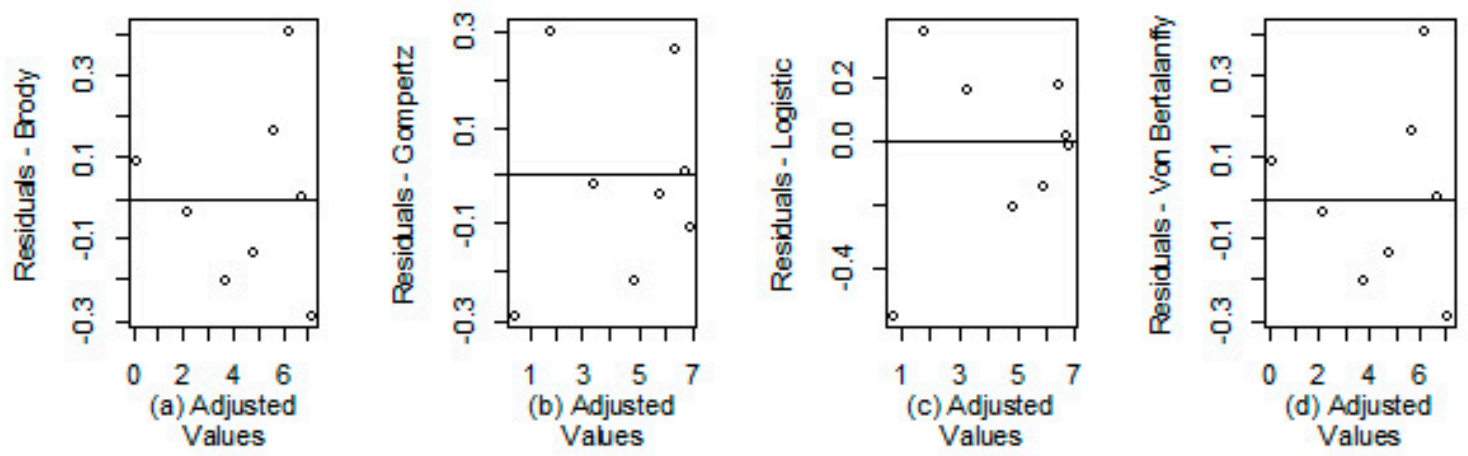

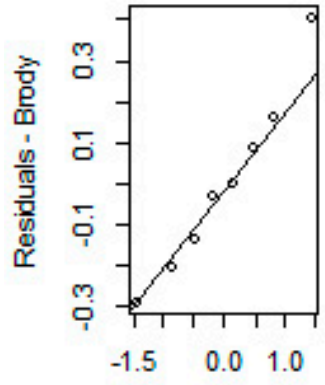

(e) Theoretical Amounts

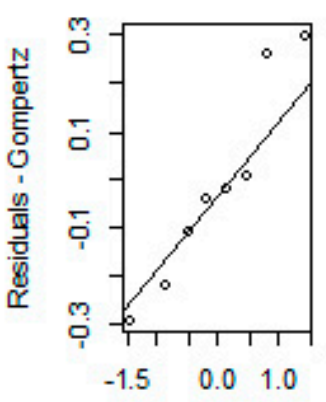

(f) Theoretical Amounts

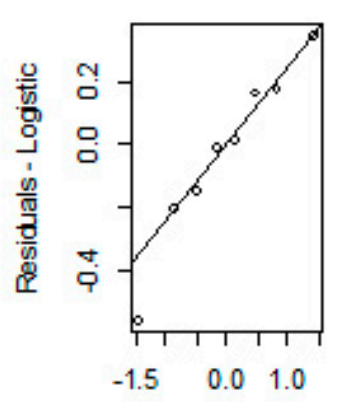

(g) Theoretical Amounts

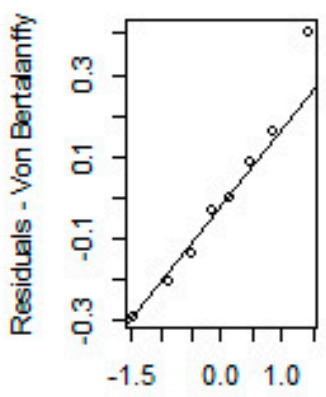

(h) Theoretical Amounts

Figure 3. Residual analysis for the Longitudinal Diameter (cm), where (a), (b), (c) and (d) represent the adjusted values in relation to residuals, and in (e), (f), (g) and $(\mathrm{h})$, the residual values in relation to theoretical amounts for Brody, Gompertz, Logistic and Von Bertalanffy models, respectively. 


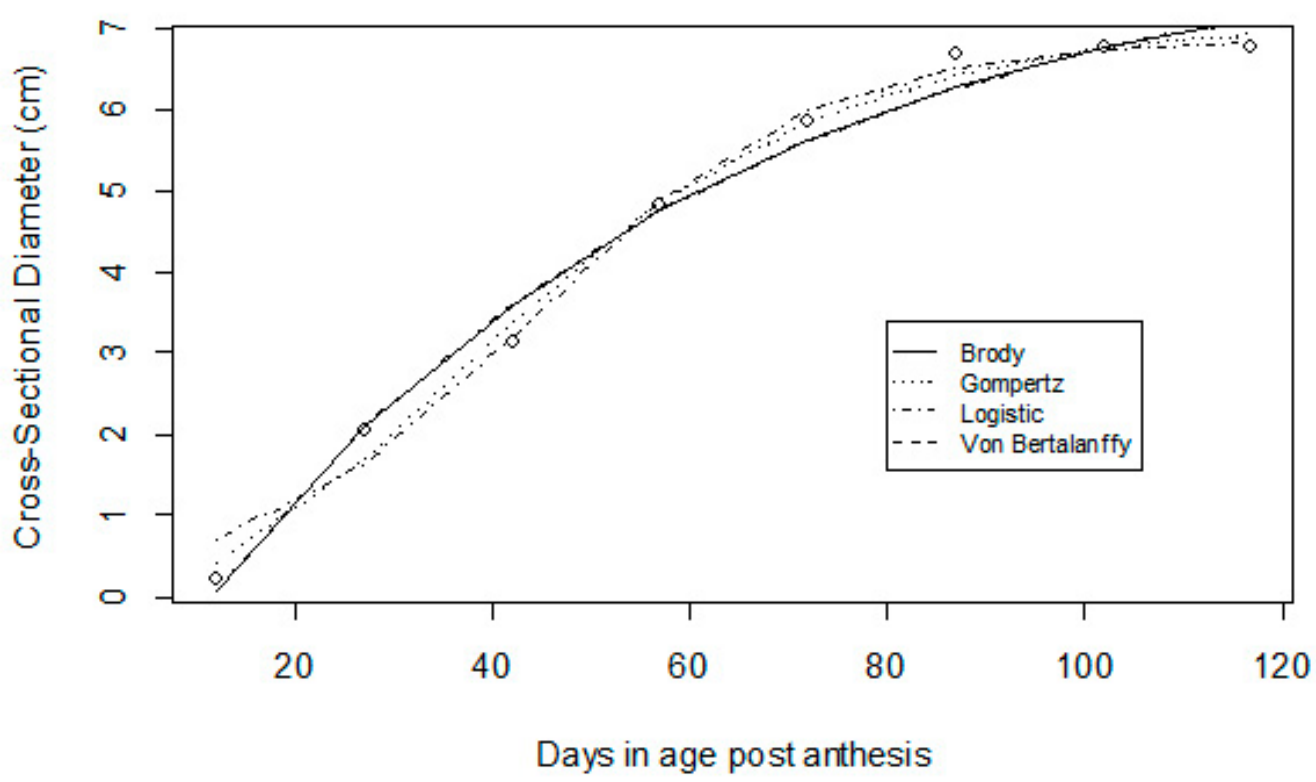

Figure 4. Adjustment of Brody, Gompertz, Logistic and Von Bertalanffy models to the cross-sectional diameter (cm) data of pequi fruits.

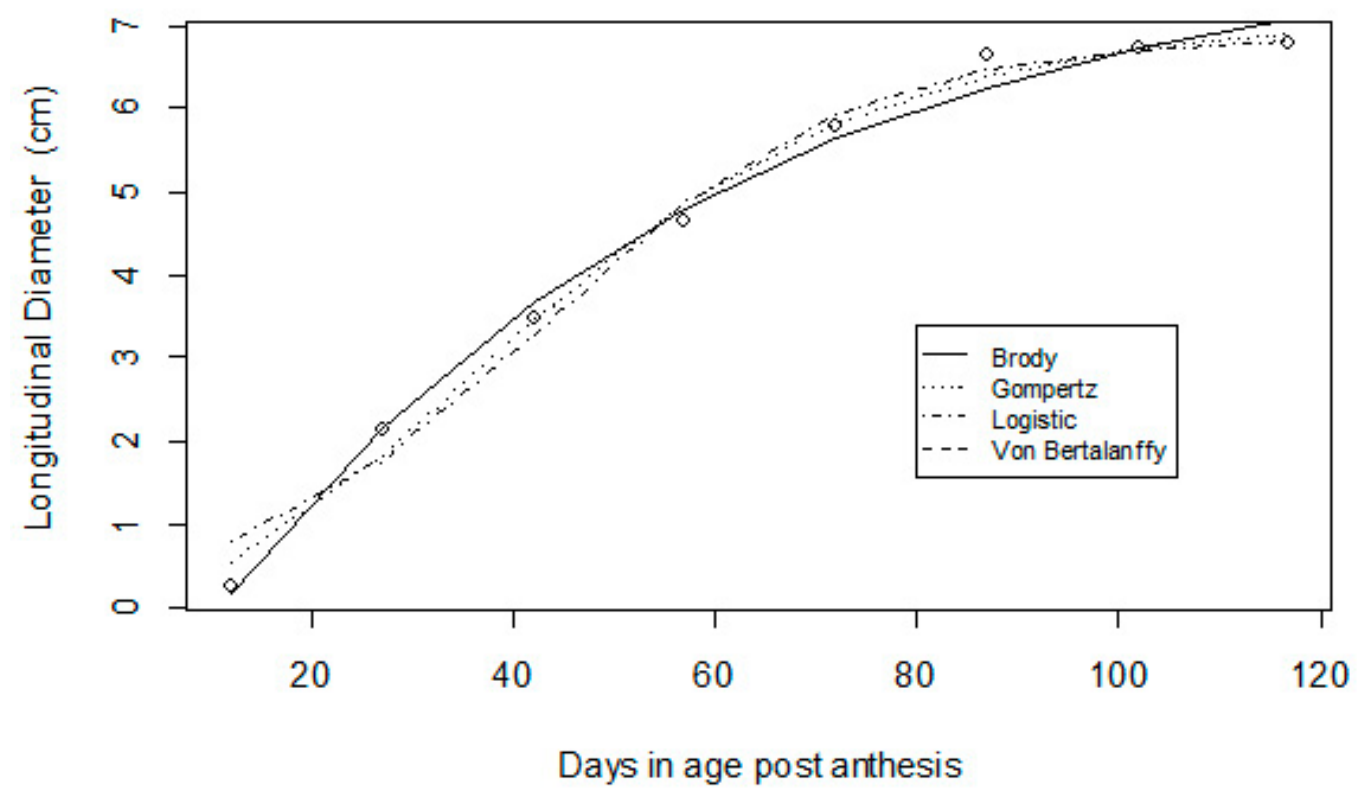

Figure 5. Adjustment of Brody, Gompertz, Logistic and Von Bertalanffy models to the longitudinal diameter (cm) data of pequi fruits. 

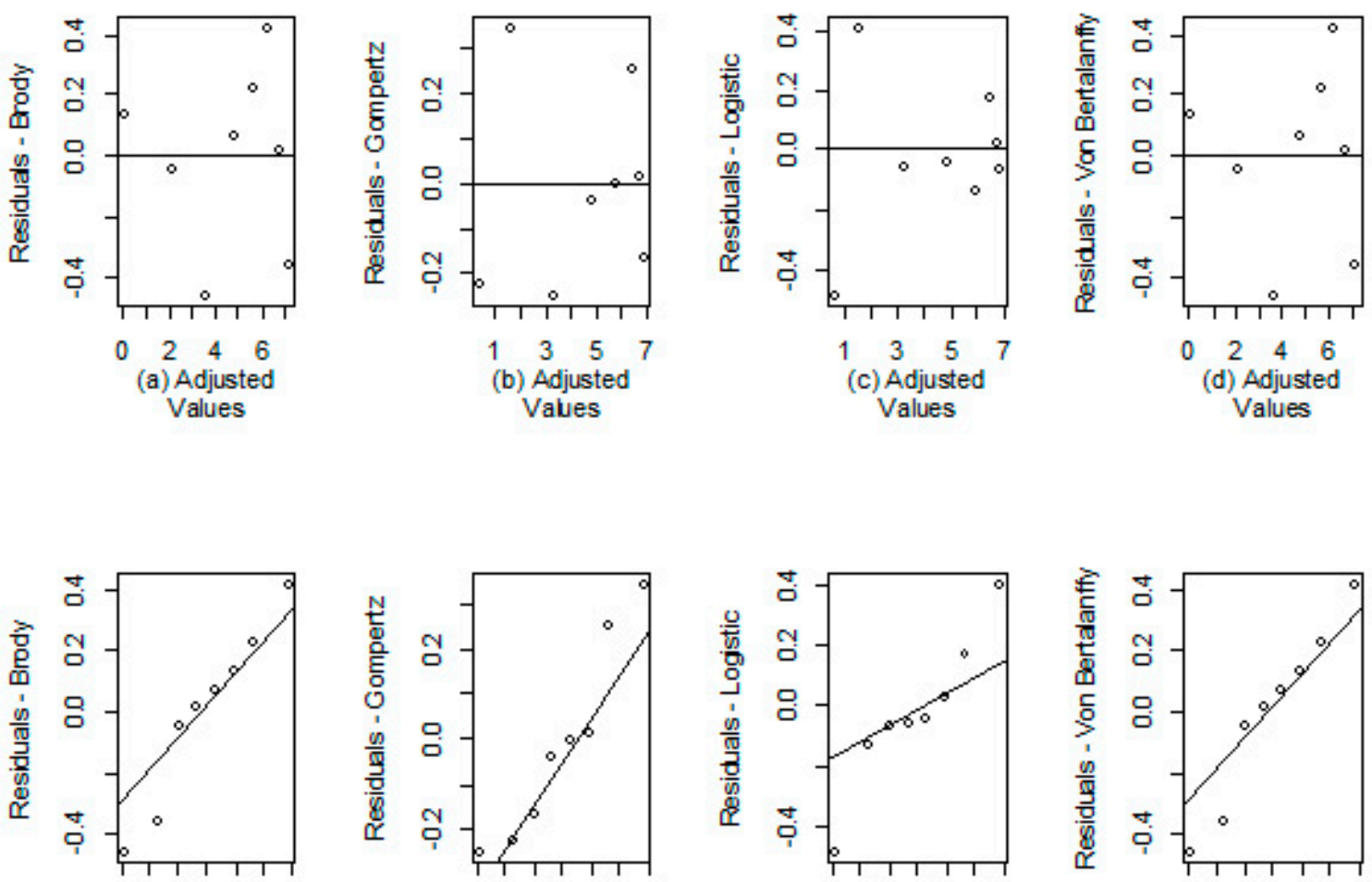

Figure 6 . Adjustment of Brody, Gompertz, Logistic and Von Bertalanffy models to the fresh mass (g) data of pequi fruits.

\section{Conclusions}

For the environmental conditions in which data were obtained, the growth of pequi fruits showed a sigmoidal characteristic described by nonlinear regression models. In general, the Gompertz and Logistic models presented good quality indicators of fit, with Gompertz model being the most adequate to describe variables, cross-sectional diameter, longitudinal diameter and fresh mass. The Von Bertalanffy and Brody models did not present good fit.

Based on the Gompertz model, the growth in crosssectional diameter $(\mathrm{cm})$, longitudinal diameter $(\mathrm{cm})$ and fresh mass (g) stabilized at 90 days after anthesis. Pequi fruits had growth rates of $0.04 \mathrm{~cm} /$ day; $0.042 \mathrm{~cm} /$ day and $0.069 \mathrm{~g} /$ day with average final dimensions for harvest of $7.11 \mathrm{~cm}, 6.85 \mathrm{~cm}$ and $113 \mathrm{~g}$, for cross-sectional diameter, longitudinal diameter and fresh weight, respectively.

\section{References}

ALMEIDA, S.P. de. Frutas nativas do cerrado: Caracterização físico-química e fonte potencial de nutrientes. In: SANO, S.M.; ALMEIDA, S.P. de (Ed.). Cerrado: ambiente e flora. Planaltina: Embrapa, 1998. p.247-285.
ARAÚJO NETO, S.E.; PRAÇA, E.F.; CARVALHO, E.F.; ALVES, R.E.; MENEZES, J.B.; MORAIS, E.A. Desenvolvimento de frutos de sapotizeiros. Revista Brasileira de Fruticultura, Jaboticabal, v.23, n.1, p.2529, 2011.

BALAGUERA-LÓPEZ, H.E.; ARÉVAlO, A.H.; MORENO, D.C. Growth of champa fruit under agroecological conditions of Miraflores, Boyacá, Colombia. Pesquisa Agropecuária Brasileira, Brasília, DF, v.47, n.12, p.1722-1730, 2012.

BREUSCH, T.S.; PAGAN, A.R. A simple test for heterocedasticity and random coeficiente variation. Econometrica, New York, v.47, n.5, 1287-1294,1979.

BURNHAM, K.P.; ANDERSON, D.R. Model selection and multimodel inference: a practical informationtheoretic approach. New York: Springer, 2002.

CARNEIRO, A.P.S.; MUNIZ, J.A.; CARNEIRO, P.L.S.; MALHADO, C.H.M.; MARTINS FILHO, R.; SILVA, F.B. Identidade de modelos não lineares para comparar curvas de crescimento de bovinos da raça Tabapuã. Pesquisa Agropecuária Brasileira, Brasília, DF, v.49, n.1, p.5762, 2014. 
CARRAZZA, L.R.; D’ÁVILA, J.C.C. Manual tecnológico de aproveitamento integral do fruto do baru. Brasília, DF: Instituto Sociedade População e Natureza, 2010.

CARVALHO, P.E.R. Pequizeiro Caryiocar brasiliensis. Brasília: Embrapa, 2009. 10p. (Comunicado Técnico, 230).

CASSIANO, F.R. SÁFADI, T. Modelos de crescimento animal para tempos irregulares. Pesquisa Agropecuária Brasileira, Brasília, DF, v.50, n.11, p.1114-1119, 2015.

CAVALINI F.C.; JACOMINO, A.P.; LOCHOSKI, M.A.; KLUGE, R.A.; ORTEGA, E.M.M. Maturity indexes for 'Kumagai' and 'Paluma' guavas. Revista Brasileira de Fruticultura, Jaboticabal, v.28, n.1, p.176-179, 2006.

DRAPER, N.R.; SMITH, H. Applied regression analysis. $3^{\text {rd }}$ ed. reprint. New York: John Wiley, 1998. 706 p.

DUBOC, E.; FRANÇA, L.V.; FRANZON, R.C.; VIEIRA, E.A.; JUNQUEIRA, N.T.V. Atributos biométricos e teor de extrato etéreo de acessos de pequi (Caryocar spp.) como potencial de produção de biocombustível. Dourados: Embrapa, 2013. 26 p. (Boletim de Pesquisa e Desenvolvimento, 64).

DURBIN, J.; WATSON, G.S. Teste de correlação serial em mínimos quadrados de regressão I. Biometrika, London, v.37, p.409-428, 1950.

FERNANDES, T.J.; MUNIZ, J.A.; PEREIRA, A.A.; MUNIZ, F.R.; MUIANGA, C.A. Parameterization effects in nonlinear models to describe growth curves . Acta Scientiarum. Technology, Maringá, v.37, p.397, 2015.

FERNANDES, T.J.; PEREIRA, A.A.; MUNIZ, J.A.; SAVIAN, T.V. Seleção de modelos não-lineares para a descrição das curvas de crescimento do fruto do cafeeiro. Coffee Science, Lavras, v.9, p.207-215, 2014.

FIORAVANÇO, J.C.; ANTONIOLLI, L.R. Pera: o produtor pergunta, a Embrapa responde. Brasília, DF: Embrapa Uva e Vinho, 2016. 229p. (Coleção Criar, Plantar).

FREITAS, A.R. Curvas de crescimento na produção animal. Revista Brasileira de Zootecnia, Viçosa, MG, v.34, n.3, p.786-795, 2005. Disponível em: $\leq \mathrm{http}: / /$ www.scielo.br/scielo.php?script $=$ sci arttext\&pid $=\mathrm{S} 1516$ -

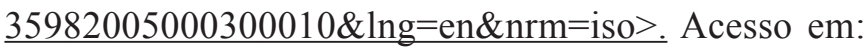
08 fev. 2017.
GUEDES, T.A.; ROSSI, R.M.; MARTINS, A.B.T.; JANEIRO, V.; CARNEIRO, J.W.P. Applying regression models with skew-normal erros to the height of bedding plants of Stevia rebandiana (Bert) Bertoni. Acta Scientiarum Technology, Maringá, v.36, n.3, p.463468, 2014.

GUTHERY, F.S.; BURNHAM, K.P.; ANDERSON, D.R. Model Selection and Multimodel Inference: A Practical Information-Theoretic Approach. The Journal of Wildlife Management. v.67, n.3, p.655. Available at: $<$ http://dx.doi.org/10.2307/3802723>. Accessed: Jan., 16, 2018. doi: doi:10.2307/3802723.

IBGE - Instituto Brasileiro de Geografia e Estatística. Produção da extração vegetal e da silvicultura (1990 a 2015) - Pequi: Brasil. Rio de Janeiro, 2017. Disponível em: $\leq$ https://sidra.ibge.gov.br/Tabela/289\#resultado $>$ Acesso em: 09 fev. 2017.

LÚCIO, A.D.; SARI, B.G.; RODRIGUES, M.; BEVILAGYA, L.B.; VOSS, H.M.G.; COPETTI, D.; FAÉ, M. Modelos não-lineares para a estimativa da produção de tomate do tipo cereja. Ciencia Rural, Santa Maria, v. 46, n. 2, p. 233-241, 2016.

MARO, L.A.C.; PIO, R.; SILVA, T.C.; PATTO. L.S. Ciclo de produção de cultivares de framboeseiras (Rubusidaeus) submetidas a poda drástica nas condições do sul de Minas Gerais. Revista Brasileira de Fruticultura, Jaboticabal, v.34, n.2, p.435-441, 2012.

MAZZINI, A.R.A.; MUNIZ, J.A.; SILVA, F.F.; AQUNO, L.H. Curva de crescimento de novilhos Heroford: heterocedasticidade e resíduos auto-regressivos. Ciência Rural, Santa Maria, v.35, n.2, p.422-427, 2005.

MEDAETS, J.P. (Coord.). Agricultura familiar e uso sustentável da agrobiodiversidade nativa. Brasília: Ministério do Desenvolvimento Agrário, 2006. 172p.

MENDES, P.N.; MUNIZ, J.A.; SILVA, F.F.; MAZZINI, A.R. Modelo logístico difásico no estudo do crescimento de fêmeas da raça Hereford. Ciência Rural, Santa Maria, v. 38, n.7, p.1984-1990, 2008.

MOURA, N.F.; CHAVES, L.J.; NAVES, R.V. Caracterização física de frutos de pequizeiro (Caryocar brasiliense Camb) do cerrado. Revista Árvore, Viçosa, MG, v.37, n.5, p.905-912, 2013. Disponível em: $\leq$ http:// www.scielo.br/scielo.php?script $=$ sci arttext\&pid $=\mathrm{S} 0100-$ $67622013000500013 \& \operatorname{lng}=$ en $\& n r m=i s o>$. Acesso em: 18 dez. 2016. 
MUIANGA, C.A.; MUNIZ, J.A.; NASCIMENTO, M.S.; FERNANDES, T.J.; SAVIAN, T.V. Descrição da curva de crescimento de frutos do cajueiro por modelos não lineares. Revista Brasileira de Fruticultura, Jaboticabal, v.38, n.1, p.22-32, 2016.

MUNIZ, J.A.; NASCIMENTO, M.S.; FERNANDES, R.J. Nonlinear models for description of cacao fruit growth with assumption violations. Revista Caatinga. Mossoró, v.30, n.1, p.250-257, 2017. Disponível em: $<$ http://www. scielo.br/scielo.php?script $=$ sci arttext\&pid $=\mathrm{S} 1983-$ 21252017000100250\&lng=en\&nrm=iso $>$. Acesso em: 16 fev. 2017.

OLIVEIRA, M.E.B.. GUERRA, N.B.; BARROS, L. de M.; ALVES, R.E. Aspectos agronômicos e de qualidade do pequi. Fortaleza: Embrapa, 2008. 32p. (Documentos, 113).

PEREIRA, A.A.; MORAIS, A.R., SCALCO, M.S.; FERNANDES, T.J, Descrição do crescimento vegetativo do cafeeiro cultivar Rubi MG 1192, utilizando modelos de regressão. Coffee Science, Lavras, v.9, n.2, p. 236$271,2014$.

PEREIRA, J. M.; MUNIZ, J.A; SILVA, C.A. Nonlinear models top redict Nitrogen mineralization in na oxisol. Scientia Agricola, Piracicaba, v. 62, n. 4, p. 395-400, 2005 .

PRADO, T.K.L.; SAVIAN, T.V.; MUNIZ, J.A. Ajuste dos modelos Gompertz e Logístico aos dados de crescimento de frutos de coqueiro anão verde. Ciência Rural, Santa Maria, v.43, n.5, p.803-809, 2013 b.

PRADO, T.K.L; MUNIZ, J.A.; SAVIAN, T.V.; SÁFADI, T.. Ajuste do modelo Logístico na descrição do crescimento de frutos de coqueiros não verde por meio de algoritmos iterativos MCMC. Revista Brasileira de Biometria, São Paulo, v.31, p.216-232, 2013 a.

R DEVELOPMENT CORE TEAM. R: a language and environment for statistical computing. Vienna: $\mathrm{R}$ Foundation for Statistical Computing, 2014. Disponível em: <http://www.R-project.org/>. Acesso em: 10 mar. 2014.
RIBEIRO, T. D. et al. The use of the nonlinear models in the growth of pears of 'Shinseiki' cultivar. Ciência Rural, Santa Maria, v. 48, n. 01, e20161097, jan. 2018. Avaliable from: < http://www.scielo.br/scielo.php?script=sci $\underline{\text { arttext } \& \text { pid }=\text { S0103-84782018000100201\&lng=en\&t }}$

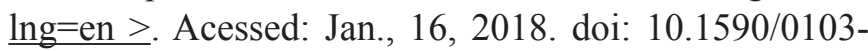
$8478 \mathrm{cr} 20161097$.

RODRIGUES, L.J.; VILAS BOAS, E.V.B.; PAULA, N.R.F.; ALCÂNTARA, E.M. Caracterização do desenvolvimento de pequi (Caryocar brasiliense) temporão do sul de Minas Gerais. Pesquisa Agropecuária Tropical, Goiânia, v. 39, n. 3, p. 260-265, 2009.

SHAPIRO, S.S.; WILK, M.B. An analysis of variance test for normality. Biometrika, Cambridge, v.52, n.3, p.591-611, 1965.

SOUSA, TF.; KUNZLE NETO, J.E.; MUNIZ, J.A.; GUIMARÃES, R.M.; SAVIAN, T.V.; MUNIZ, F.R. Fitting nonlinear autoregressive models to describe coffee seed germination. Ciência Rural, Santa Maria, v.44, p. 2016-2021, 2014.

SOUZA, G. da S. Introdução aos modelos de regressão linear e não linear. Brasília: Embrapa, 2007. 505p.

TERRA, M.F.; MUNIZ, J.A.; SAVIAN, T.V. Ajuste dos modelos Logístico e Gompertz aos dados de crescimento de frutos da tamareira-anã (O’brien). Magistra, Cruz das Almas, v.22, n.1, p.1-7, 2010.

VERA, R.; SOUZA, E.R.B.; FERNANDES, E.P.; NAVES, R.V.; SOARES JUNIOR, M.S.; CALIARI, M.; XIMENES, P.A. Caracterização física e química de frutos do pequizeiro (Caryocar brasiliense Camb.) oriundos de duas regiões no estado de Goiás, Brasil. Pesquisa Agropecuária Tropical, Goiânia, v.37, n.2, p.93-99, 2007.

WYZYKOWSKI, J.; CUSTÓDIO, A.A.P.; CUSTÓDIO, A.A.P.; GOMES, N.M.; MORAIS, A.R. Análise do diâmetro de copa do cafeeiro recepado utilizando um modelo não linear misto. Revista Brasileira de Biometria, São Paulo, v.33, n.3, p.243-256, 2015.

ZEVIANI, W.M.; SILVA, C.A.; CARNEIRO, C.J.O.; MUNIZ, J.A. Modelos não lineares para a liberação de potássio de estercos animais em latossolos. Ciência Rural, Santa Maria, v.42, n.10, p.1789-1796, 2012. 